\title{
Langhåret livsstil
}

\section{Av NILS CHRISTIE}

Lange, flagrende lokker, skjegg hos dem som kan få til slikt, en eiendommelig klesdrakt, gitar $\mathrm{i}$ hånden og bjeller om halsen, bare føtter på sommertid og kanskje en litt mangelfull personlig hygiene sommer såvel som vinter, - mon tro om det ikke er fenomen med krav på interesse utover den billige som er alle rarieteter til del. Mon tro om det ikke er riktig å se på disse trekk som et rikt utvalg av signaler om at man står for noe annet enn det vanlige i samfunnet, at man mener og kanskje også handler annerledes over et bredt register av livsområder, og at man i samlet sum er representant for en livsstil i kontrast til mye vi andre tar som gitt.

Denns livsstil, selv de spede spirer av den som vi finner her i Norden, den sier oss kanskje noe av betydning om vår egen tid. Den sier oss kanskje noe om hvem vi er — begge parter - og kanskje også om hvem vi kommer til å bli. Fordi det på denne

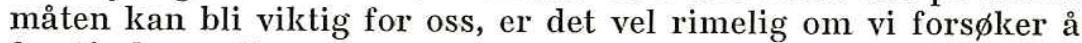
forstå denne livsstilen selv om vanskelighetene er helt ekstraordinært store. Det hersker et kasteskille mellom de utgamle som fors $\varnothing \mathrm{ker}$ å analysere fenomenet, og kulturens egne representanter ( „Never trust a man over thirty“.) Det gjør innlevelse vanskelig, og materialinnsamling enda vanskeligere. Empiriske unders $\varnothing$ kelser finnes nesten ikke ${ }^{1}$. Det er heller ikke lett avgrensbare fenomen vi har med å gjøre. Det finnes kortklippede langhårede, og sikkert også adskillige langhårede med en sterkt beklippet livsstil både $i$ holdninger og handlinger. Noen nyanser vil bli sluppet til etter hvert, men ikke mange - temaets størrelse tvinger til konsentrasjon om hovedlinjene. Beskrivelsen blir overforenklet, i første halvdel av artikkelen kanskje også litt idealisert. For bedre å være under leserens kontroll bør kanskje sies at jeg liker mye i den livsstil jeg skal fors $\varnothing$ ke å beskrive. Den rommer avgjorte farer og problemer, men også viktige verdier, - kanskje for oss alle.

$\mathrm{Jeg}$ vil f $\phi$ rst fors $\varnothing \mathrm{ke}$ å analysere noen forutsetninger for og hovedtrekk ved dette fenomenet. Deretter vil jeg antyde noen

1) Noe av materialet til det følgende har jeg fra et fascinerende spesialnummer av Transaction (Washington Univ. St. Louis, Missouri) desember 1967. Noe er inspirert av Simmons og Winograds ,It's happening", St. Barabra 1967, noe av Magnus Kihlbom om „Hippie-protesten ", og noe også av to artikler av vit. ass. Brit Bergersen $i$ Universitetets kronikktjeneste desember 1967. Men det meste er refleksjoner basert på spredt lesing og nokså enkle observasjoner. Mange har formodentlig vært inne på det samme. 
problem denne livsstilen representerer. Men jeg gjentar: Særlig troverdig blir intet av det følgende. De fenomenene vi skal beskjeftige oss med er vanskelig tilgjengelige for forskning. Samtidig har kanskje flere af oss den følelse at kunne vi klare å finne en nøkkel til å forstå dem, så fant vi en nøkkel til mange låser, - og viktige. Det er vel derfor rimelig om vi beveger oss bort fra de opplyste områder uten svar på det vi virkelig gjerne vil vite, og over i skumringslandet med dets mange muligheter for feil såvel som for innsikt og uventede funn.

\section{Antikonsumenter.}

Ett godt utgangspunkt til forståelse av hva fenomenet står for, får vi ved å legge merke til hvor det finnes, og blant hvem. Først og fremst: Det er i høy grad et internasjonalt fenomen vi er opptatt av. Det er ikke begrenset til Norge, Norden, Vest-Europa eller endog USA. Vi finner det på fjerne kontinenter som Australia og New Zeeland, og også enkelte steder i Øst-Europa. Men vi finner det ikke alle steder, og ikke alle steder like sterkt. Vi finner det, ser det ut til, mer i USA enn i Italia, og mer i Sverige enn i Norge, og sikkert mer i Vest enn i $\emptyset$ st. M.a.o.: Vi finner det mer og tidligere i de materielt rikeste land, og vi finner det nesten ikke i de fattigste. Det finnes unntak, men de får ligge.

Et ytterligere hovedtrekk går igjen innen de fleste av de land hvor fenomenet gj $\phi \mathbf{r}$ seg gjeldende: Dette avvik i symboler og livsstil, det later ikke først og fremst til å slå an blant de fattigste blant de rikeste, men blant de rikeste av de rikeste. Tydeligst blir dette i USA, hvor kontrastene er st $\varnothing$ rst. Det dreier seg om barn f $\varnothing \mathrm{dt}$ mette og oppdradd i materiell overflod så langt $\phi$ ye og skolekrets rekker. Neppe noen gang tidligere har det eksistert så store befolkningsgrupper som ikke selv eller i sine relevante omgivelser har opplevd materiell eller fysisk utrygghet. Dette er i virkeligheten, og nå nærmer vi oss det sentrale, barna til den generasjon som løste sine $\phi$ konomiske organisasjonsproblem ved å konsumere. Ved en kombinasjon av høyst naturlige lyster, privat reklame og statlig oppmuntring ble det skapt en mennesketype med de gunstigste virkninger for $\phi$ konomisk trivsel. Denne eventyrfigur av gutten som kunne kappkonsumere med hvilket som helst troll har - godt hjulpet av en og annen ytre konflikt — sikret at de fleste hjul har rullet, og at få hender, $i$ hvert fall få verdige hender, har vært helt uvirksomme.

Men om løsningen på sentrale $\phi$ konomiske organisasjonsproblem har ligget $\mathrm{i}$ konsum, så forstår man også hvor sentralt revolten — den valgte fattigdom - rammer. Blomsterbarna, det er slike som kunne levet det s $\phi$ te liv, om de bare hadde villet. Det dreier seg ikke om de på forhånd sikre tapere som avviser en del av samfunnets fundamentale bel $\varnothing$ nninger, som både de og andre 
så vel vet at de aldri kunne nå. Slik avvisning skaper ingen tvil, bare trygghet om at målet er godt. Helt annerledes blir det når den opplagte vinner gir seg til å plukke blomster istedenfor å gå i mål. Det er fra den f $\varnothing$ rste mette generasjon at noen - i enkelte land mange - tar sin skjebne i egen hånd og bevisst eller ubevisst står frem som anti-konsumentenes fremste eksempler.

Denne valgte fattigdom er selvfølgelig intet fullstendig nytt. Det nye ligger mer i disiplenes synlighet - en konsekvens av de moderne massemedia - deres frittflytende tilgjengelighet en konsekvens av at relativt flere er ,under utdannelse“ nå enn noengang tidligere, og så dette at de rekrutteres ovenfra, - en konsekvens av at fattige $i$ forbrukerkulturen f $\varnothing$ rst må bli rike f $\varnothing \mathrm{r}$ de vil bli fattige.

Men så er de da til sist blitt fattige til gagns. I kondemnerte hus, i krypinn i kjellere, eller i improviserte skur leves det sammen etter prinsippet om at den som har, gir, og at alle yter etter evne. En særlig raffinert provokasjon mot det pene samfunn er at en av innkomstkildene er betling. En dobbelt provokasjon er at betlingen ikke skjer ydmygt, men som en selvf $\varnothing$ lgelig rett.

\section{Tilbaketrekkere.}

De er antikonsumenter fra den første mette generasjon. La det være mitt f $\phi$ rste hovedpunkt. Men samtidig, og det leder meg over til mitt annet, men kanskje viktigere punkt, samtidig tilh $\phi$ rer de den f $\varnothing$ rste generasjon hvor det er blitt en selvf $\varnothing$ lge at intet folkerikt sted i verden er lenger enn en dagsreise borte. Det skaper pinlige kontraster i velstand, noe som ofte leder til brennende politisk engasjement langt borte fra hippienes verden. Men det skaper også pinlige kontraster mellom idealer og muligheter for realisering av idealene. Med $\phi \mathrm{kt}$ kommunikasjon f $\varnothing l g e r$ tendenser til at det blir skapt større organisas joner på en lang rekke livsområder - innen industri, handel, politikk, estetikk, og utdannelse. Men st $\varnothing r r e$ enheter betyr som oftest organisasjoner med mindre villighet til eksperimentering og radikale endringer. For mye står på spill, og det blir for mange bindinger. St $\varnothing$ rre enheter betyr også følt og faktisk mindre innflytelse, for de fleste avgjørelsene blir fattet lengere borte. Om verden er blitt mindre, så er en selv blitt enda meget mindre nettopp fordi organisasjonene er blitt så store. Denne følte maktesløshet i de store organisasjoners samfunn kan, sammen med mange andre str $\varnothing$ mninger, føre til ekstreme politiske handlingsvalg. Men den kan også lede henimot det som ligger vårt tema nærmest: Til tilbaketrekning, til avvisning av hele spillet og til en vandring inn $i$ alternative verdener. Formodentlig har forsvarsminister Mc Namara skapt flere blomsterbarn enn all verdens musikanter. Sikkert er det, at mange av de klarest verbaliserende hippier ser på sin livsstil 
som det eneste alternativ $\mathrm{i}$ en vanvittig politisk situasjon. De ser på radikal politikk av typen ytterste ytre venstre som fåfengte overflatekrusninger dømt til både å mislykkes og til å korrumperes. Som Magnus Kihlbom skildrer ${ }^{1}$ ):

„Möjligheten att förbättra världen ligger i stället $\mathrm{i}$ att så många som möjligt ,vidgar sitt metvetande“, ökar sin empati och sin kärlek, ,turn on“", och flyr från det petrifierade massamhället till en riktigare tillvaro, „,drop out“. När blomstergenerationen, eller deras barn, har vuxit upp, har de återstående „Squares“ dött ut, maktens institutioner och apparater har vittrat ner, och mänskligheten lever i aggressionsfria, öppna småsamhällen och storfamiljer.“

\section{3. Øyeblikksorienterte.}

Dypt $\mathrm{i}$ arven fra den protestantiske etikk ligger troen på at det er $i$ fremtiden den virkelige l $\phi \mathrm{nn}$ vil komme. Man arbeider idag for å gledes imorgen. Dagens barn har kunnet drukne seg i konsumvarer innkjøpt for gårsdagens utsatte behovstilfredsstillelser. Men om mål og makt ikke lenger frister, så blir også utsettelsen utjenlig. I tillegg kommer andre faktorer, en teknisk utvikling som gjør det åpenbart for alle som vil se at færre og færre kan produsere mere og mere, og også med så hastige skifte i teknikk at dagens lærdom lett blir en hemsko for morgendagen. Og som det helt avgjørende for mange: En morgendag som kanskje aldri blir.

Til sammen blir det mange krefter som bidrar til å gi denne kultur dens preg av å være фyeblikksorientert eller nåtidsorientert. Her og nå er ditt liv, dine gleder, dine sorger. Utallige er de utsagn man møter om denne ungdoms manglende respekt for avtaler, klokkeslett, presisjon. Dagen har ingen slutt, og den neste ingen begynnelse. Klokker er uønsket $\mathrm{i}$ alle andre former enn som bjeller om halsen. På dette punkt er det interessante likheter i livsstil mellom hippiene og det vi møter innen de aller laveste samfunnslag innen storbyene og muligens også innen bondebefolkningen i enkelte latinske land. Årsakene til nåtidsorienteringen er forskjellige, - blant blomsterbarna valg, i storbyslummen skjebne. Men i begge tilfelle blir dagen viktigere enn morgendagen.

Likheten må imidlertid ikke presses for langt. Det blir klart når vi går over til punkt fire, som har med livsorientering å gjøre.

\section{Livsorientering.}

Hvor ting og tid og politisk makt ikke teller, der trer andre verdier inn isteden. Her føler jeg meg på ekstra gyngende grunn,

1) Kihlbom, Magnus: Hippie-Protesten. Stensil 1967, 9 s. 
og vil advare spesielt sterkt mot alt jeg sier. For samtidig som dette er et kjernepunkt, så er det også uendelig vanskelig å gripe fatt i de strømninger som gjør seg gjeldende, forstå dem, og formidle et inntrykk av dem til andre. Men noen stikkord kan jeg vel fors $\varnothing \mathrm{ke}$ meg med. Det er en indreorientert kultur det dreier seg om. Introspeksjon spiller en viktig rolle, følelser og opplevelser har h $\phi y$ rang. Karakteristisk, for idealene i hvert fall, er at spørsmålet til den fremmede ikke lyder ,hva er du“ - med forventninger om yrkesangivelse - men „hvem er du?“. Hva slags menneske med hvilke typer ressurser, spesielt til indre opplevelser, er det du er? Kjærlighet, åpenhet og toleranse blir ord som sin løshet til trods ikke blir å komme forbi. Og fra dette utgangspunkt åpner det seg mange veier. Én går mot kunst, opplevelsen av kunst, eller opplevelsen i kunstnerisk utfoldelse. En annen går mer i kontemplativ retning, affiniteten mellom hippier og mystisisme er klar. En tredje går mer i retning av samvær og samliv med andre. Også nokså lite diskriminerende distribusjon av fysisk kjærlighet kommer her inn som en naturlig komponent. At friheten samtidig kan erte de forgagne, $\varnothing \mathrm{ker}$ formodentlig forn $\varnothing$ yelsen. Ved alle disse veier er bruk av kjemiske midler for å nå enda større opplevelser, en nærliggende mulighet. Jeg skal snart komme tilbake til dette.

Også disse veier står nokså fjernt fra den ungdom vi vanligvis møter i de mer underpriviligerte nabolag. Mitt inntrykk er i hvert fall at dette er en langt mer kontrollert ungdom, mer innkapslet, mer på vakt. Hvis noe skulle settes opp som den ekstreme kontrast til den langhåredes litt utflytende bejaende opplevelsestolerante livsform, så var det vel nettopp den av bitter nødvendighet tilkjempede sikre overflate hos den tradisjonelle underpriviligerte. Der finner vi gutten med så mange arr fra sin fortid at han har skapt seg en form hvor den dominerende symbolikk er ,to play it cool“. Begge typer er på jakt etter spenning. Men blomsterbarnets jaktmarker går innover hvor slumguttens går utover.

Jeg nevnte i det foregående at jeg hadde adskillige vanskeligheter med å formidle inntrykket av den indreorienterte livsholdning det her dreier seg om. Og jeg kunne lagt til at jeg formodentlig deler denne vanskelighet med livsstilens egne representanter. Det er diffuse, dårlig uttrykkbare, og derved lite målbare kjennetegn det dreier seg om. Men derved er sagt mye mer, ja kanskje det viktigste om hele livsorienteringen. For derved er sagt at det blir høyst problematisk å foreta rangeringer innen dette systemet. Det blir vanskelig å komme med påstander om hvem som er best, eller værst, hvem som er det gode blomsterbarn, hvem som ikke er fullt så god, og hvem som er rent ilde. Hvor normene er tungt ekspliserbare, der blir det også tungt å skille mellom tapere og 
vinnere. Og som vanlig i sosialt liv, kan dette være både til godt og til ondt. De manglende standarder skaper aktivitet, utfoldelse, nye veier, nye opplevelser. Det oppmuntrer til eksentrisitet, det hemmer konkurransetendenser, og helt generelt: Det gjør rangsforskjellene i systemet små, det skaper lite autoritære samværsformer vel tilpasset tilbaketrekningen fra de store organisasjoner. Men samtidig skaper mangelen på presise normative styringer også muligheter for fatale feiltrinn. En åpenbar vanskelighet ved de ikke autoritære samværsformer viser seg i situasjoner hvor det blir viktig ả koordinere blomsterbarna til samlet innsats om et komplisert mål. Slike situasjoner har oppstått nokså mange ganger i Hippienes begivenhetsrike fortid. Ofte går det galt. Matstasjoner er riktignok holdt i drift i lange perioder, butikker med gratis tiltuskede varer likeså. Men en gammel kyniker kan vel av og til spørre seg selv om hvor meget av dette - og av hele denne tilværelsen for $\phi$ vrig - som ville vært mulig om den ikke var bygget utenpå et helt annet sett av normer, og med retrettmuligheter over til en annen verden - om nøden skulle bli for stor.

\section{Estetikk.}

Men på samme måten som den nye livsstil kan sees som en reaksjonsdannelse mot konsum av ting og av makt, så er den også i stor utstrekning en reaksjonsdannelse mot konsum av estetiske produkter. $\mathrm{Og}$ det er gjort på en snedig måte. I en verden hvor de fleste av oss passifiseres i vår personlige utfoldelse ved til daglig å bli — eller kunne bli - konfrontert med estetikkens mesterverker formidlet til oss av verdenshistoriens mesterformidlere, i denne verden er spillet slått over ende ved lanseringen av helt nye estetiske former som de gamle forel $\phi$ pig ikke vet opp ned på, ved instrumenter og uttrykksmidler som også tildels er helt nye, ved å sette normen om deltakelse fremfor perfeksjonisme i høysetet, og så endelig - men som det helt avgjørende - ved å innføre en norm på estetikkens område om at ingen gamle normer gjelder. Men hvor de estetiske standardene faller, der, som på andre livsområder, faller mulighetene for rangering. Det skaper apati i et sosialt system hvor belønningene er knyttet til å være den beste. Men det skaper aktivitet $\mathrm{i}$ et system hvor bel $\varnothing \mathrm{n}-$ ningene er knyttet til selve utfoldelsen og de indre opplevelsene dette gir.

Men denne situasjon er selvfølgelig labil. Sterke krefter presser på ikke bare for å gjenskape gamle standarder, men for å skape nye. Økonomi såvel som konkurranselyst gjør seg gjeldende. Like fremmende som The Beatles har vært når det gjelder å bryte med standarder, like hemmende kan de bli overfor tilstanden av bestående normativ løshet på estetikkens område. Dobbelt sterkt 
blir dette press i retning av klare standarder fordi så mange av disse nye kulturelementer egentlig er overtatt fra den gamle underklasse, med dens lave toleranse for normativ l $\phi$ shet på estetikkens såvel som på de generelle livsutfoldelsers områder.

\section{Kjønnssymbolikk.}

Et sjette og siste punkt viser også den fundamentale forskjell mellom de frivillige og de ufrivillige fattige. Om noe er karakteristisk for gammeldagse gjeng-medlemmer i et fattig nabolag, så er det deres maskuline preg, betydningen av fysisk styrke, vågemot, kampvilje og evne. Kanskje er denne maskulinitet i noen grad usikkert fundert basert på kvinnedominerte husholdninger med manglende eller sterkt vekslende fedre. Men den er der, i overveldende styrke for den som kommer til kort, og kanskje også for den som kommer for langt.

I kontrast til dette, og vel også i kontrast til det vanlige norske middelklassem $\varnothing$ nster, finnes det enkelte feminine trekk i den langhårede kultur. Noe av provokasjonen ligger vel nettopp i dette, og er tatt vel vare på $\dot{i}$ noen av de ytre attributter. Introspeksjonen, betydningen av фyeblikket, den h $\phi$ ye vurdering av f $\varnothing$ lelsesmessige kvaliteter, av ikke autoritære samværsformer, og også kjærlighetsevangeliet og anti-vold tendensene, peker alt $i$ samme retning. A kalle dette en utpreget feminin kultur er formodentlig å gå for langt. Mer treffende er vel å si at vi er konfrontert med en kultur hvor det i symbolikk er skjedd en tilnærming - hvor kjønn vises mer ved biologi enn ved broderi.

\section{Noen nyanser.}

Intet av det som hittil er sagt er vel helt treffende for noen enkelt langhåret person. Det meste jeg har kunnet håpe, er at noen hovedtendenser er fanget opp. Men i hvert fall to nyanser må nevnes:

Først og fremst er det klare forskjeller i politisk engasjement. På den ene side møter vi de retninger som f. eks. provoene i Holland og de langhårede student-politikerne ved mange universiteter representerer, og så på den annen side de langt mer passive, politisk likegyldige tilbaketrekkere. - Et annet for en nordmann vesentlig skille gjelder som vanlig Norge kontra Verden. F $\phi$ rst og fremst: Våre hjemlige forutsetninger for det lange hår er antagelig av en noe annen art enn spesielt de amerikanske. Vi tilhører fortsatt et lite samfunn preget av de små enheter, og derved med mindre grobund for tilbaketrekning. Vårt forbrukerparadis er noe mindre fullkomment. Store befolkningsgrupper som man vel kan si at nasjonen som helhet identifiserer seg med, har ikke mer enn et løvtynt skille mellom seg og direkte fysisk 
nød. Konsumentsamfunnet er ikke ennå blitt overmodent. Reaksjonen blir mindre utpreget, og mer en reaksjon på hva som vil komme enn på hva som er. Det gjelder vel både for provo-fl $\phi$ yen og blomster-fløyen. Når det gjelder den siste fløy, spiller vel også inn at tilf $\varnothing$ rselsveiene for kjemiske midler til indre opplevelser er lengere til oss enn til de fleste andre land, og så endelig, hva som for meg står som det viktigste moment $i$ en forutsigelse om at blomsterverdenen aldri helt vil få samme karakter i Norge som i andre land: Vi har $i$ vårt land $i$ større grad enn $i$ noen annen industrinasjon jeg kjenner til, benyttet oss av alternativer til de kjemiske midler for å foreta emosjonelle reiser. Jeg sikter ikke til alkohol, selv om det godt kunne vært nevnt. Jeg sikter heller ikke til offisiell religionsutfoldelse, som later til å være vel så t $\varnothing \mathrm{rr}$ og perspektivløs hos oss som i andre industrinasjoner. Nei, jeg sikter til den eneste virkelige ressurs vi har i dette landet fremfor de fleste, og som vi også — stadig relativt sett — har visst å utnytte, jeg sikter til noe så banalt viktig som at våre byer er små og befolkningen liten, mens landet er stort og lykkeligvis for det meste fyldt med stein. Det er vel mye som tyder på at de opplevelser som man oppnår gjennom mange av de såkalte mind expanding drugs har store og vesentlige likheter med dem nordmenn opplever under sine rituelle samvær med norsk natur.

Til sammen f $\varnothing$ rer formodentlig alt dette til at det norske lange hår i noe mindre grad enn $i$ andre land har grobund i vår hjemlige situasjon, og kanskje i noe større grad er et resultat av kulturelle overf $\varnothing$ ringer. Det er litt mer lært enn skapt. Det er foreløpig også noe færre det har slått an hos i Norge enn i en del andre land. Etter alle vanlige prinsipper for utvalg til ekstrembevegelser vil dette formodentlig bety at de utvalgte vil være litt ",rarere“, de vil formodentlig ha en noe mer atypisk familiær, sosial, og intellektuell bakgrunn enn de tilsvarende i USA eller Storbritannia. Fordi vårt hjemlige miljø er så lite, vil en vel også hurtigere oppleve stilblandinger. Personer og kulturtrekk fra raggare og lærjakker vil smelte sammen med de langhårede. Knut Sveris unders $\varnothing$ kelser fra Stockholm peker i denne retning. ${ }^{1}$ )

\section{Noen vurderinger.}

Vurderingen av dette fenomenet vil nok i stor utstrekning avhenge av personlige preferanser og ikke minst av personlig livsstil. Men noen momenter bör vel under enhver omstendighet tas i betraktning.

Viktigst må være at man ikke avgrenser vurderingsgrunnlaget alt for snevert. Vurderingen av den livsstil det her dreier seg

1) Knut Sveri: Ungdom og gateopptøyer. Lov og Rett. 1967, nr. 9. s. $416-422$. 
om avhenger i meget stor grad av hva slags samfunn vi vil ha. Det er åpenbart at vi ikke lkan ta opp den diskusjonen her og nå. Men det synes meg like åpenbart at denne protestbevegelse og denne livsstil står for verdier som ingen kan påstå ikke er av betydning. Det er, når vi kommer inn til kjernen, verdier som rager svært høyt i våre aller eldste prioriteringslister. Dette maner til stor grad av forsiktighet når vi hanskes med disse verdiers bærere. Det er stadig noe ganske annet enn hår det dreier seg om.

To hovedsp $\phi$ rsmål reiser seg. For det f $\phi$ rste: Hvilke samfunnsmessige virkninger har eksistensen av denne livsstil? Spesielt: Hvor mye tåler et samfunn av anti-materialistiske kulturformer før det materielle grunnlag svikter, - og hva så med antimaterialistene? Dette er selvf $\varnothing$ lgelig ikke noe nytt dilemma, og det vil vel løses på gammelt vis ved at de to hovedstrømningene finner plass ved siden av hverandre og danner en eller anden form for likevekt. Interessant er imidlertid spфrsmålet om de rent konkrete politiske konsekvenser av hippienes livsform. De har forferdet borgerskapet, men fortvilelsen er kanskje både st $\varnothing$ rre og mer berettiget blant de ekstreme venstreradikalere. Disse opplever — antakelig helt riktig - hippie-bevegelsen som noe som tar fra dem både rekrutter og sak. Blomsterbarna mister tradisjonell politisk interesse, de vil forandre hele det politiske spillet innenfra, ikke bare deler av det slik som venstreradikalerne. Ved sin antimaterialisme bidrar de også til å gjøre det eksisterende middelklassesamfunnet mindre kritikkverdig. Det hevdes, og kanskje stadig med rette, at den langhårede livsstil har bidradd vesentlig til å ta kraften ut av venstrefløyen i amerikansk politikk, og at bevegelsen i sine konsekvenser egentlig er konserverende - at den bidrar til å stabilisere det amerikanske samfunn. Sikkert er det, at motviljen er stor i politisk radikale kretser. Når den verste forskrekkelsen har lagt seg også her hjemme, kan det meget godt hende at det blir tradisjonelt liberale kretser som vil vise størst godtagelse af denne livsstil.

Et annet hovedspørsmål gjelder selvfølgelig blomsterbarnas egen skjebne. Selv om det skulle være slik at det blomsterbarna står for er livgivende for de samfunn de opptrer innen, så kunne det være drepende for dem selv. Det er særlig tre farer som truer: De vil kunne komme yrkesmessig til kort. De vil kunne pådra seg helseskader, og de vil kunne komme i dårlig selskap og gli over fra en langhåret moral til en asosial.

Alle disse farer innebærer helt klare og ofte meget alvorlige realiteter. Lettest å avvise fra en langhåret synsvinkel er vel påstanden om de yrkesmessige farer. Det er riktig, vil den langhårede si, at jeg blir dårligere kvalifisert for en middelklassejobb. Men jeg blir bedre kvalifisert til å leve mitt indre og også 
mitt sosiale liv. Jeg får det bedre, og andre får det neppe verre. Tvert om, så letner vel konkurransesamfunnets press om samfunnet får flere alternative målsetninger å rutte med.

Vanskeligere er det å se bort fra mulighetene for helseskader. Som det litt oppgitt kom fra en lege som har fors $\varnothing$ kt å hjelpe: „Om de nå bare hadde n $\varnothing y d$ seg med å avvise samfunnets lover, ikke naturlovene også." Det er neppe tvil om at de mere ekstreme former for blomsterliv fører med seg direkte fysiske skadevirkninger for en del av ut $\varnothing$ verne. Underernæring, leverskader og kjønnssykdommer er nok noen av det ideelle livs følgetilstander. Ikke minst skyldes dette at det i så stor utstrekning dreier seg om middelklassebarn som for første gang og fullstendig uten erfaring møter slummen, og som der konkurrerer om knappe ressurser med den opprinnelige befolkning som ser med uvilje og forakt på inntrengerne.

De mentale helseskader er langt vanskeligere å vurdere. Noen har jo vært tapere fra middel- og overklassens verden også f $\phi \mathbf{r}$ hippienes fødsel. Dengang var alkohol ett naturlig middel på vegen ut og ned, den sinnsykelige adferd et annet. I dag er det vel rimelig å anta at en overkvote av potensielle tapere søker seg hen til de langhårede. Spфrsmålet blir så først og fremst om disse potensielle tapere møter ytterligere belastninger i dette milj $\phi$, eller om det kan tenkes at de tvert om har godt av å være her, hjelpes ved at andre mål gjelder, st $\varnothing$ ttes ved at standardene er få, uklare, og med stor oppmuntring til eksentriciteter. Jeg har ingen muligheter for å gi klare svar. Sannsynlig er kanskje at på forhånd overstyrte mennesker vil kunne ha godt av en dose langhåret liv, for dem kan miljøet virke som et slags terapeutisk samfunn. Og om de ikke skulle hjelpes, så kan det jo likevel representere et stort gode bare å eksistere der. Her reiser det seg et spørsmål om betydningen av å bevare alternative kulturer som kan gi legitimitet til roller som vi ellers ville plasere i anstalt. Passive, litt kraftløse personer kan kanskje også finne seg en lagune i dette miljø — selv om det kanskje kan fryktes at de derved blir ytterligere passivisert. Men mest er det vel grunn til å frykte at personer med vanlig eller ekstra sterkt aktivitetsnivå - men med et svakt utbygget sett av adferdsnormer - i denne nye verden kan komme til å møte for mye av hva de har mer enn nok av fra før. Her ligger faren for overgang fra langhåret moral til asosial. Her reiser det seg også spørsmålet om smittefaren tilbake fra disse. Et ytterligere spørsmål er om de som normalt ikke ville bli tapere, $\varnothing$ ker sine sjanser for å bli skadet ved på denne måten å fungere som terapeuter eller st $\varnothing$ ttekontakter. Her skimtes nye etiske dilemmaer. Jeg lar dem ligge.

Noen unders $\phi$ kelser av disse mulige virkninger foreligger meg bevisst ikke. En viss relevans har kanskje en liten unders $\varnothing$ kelse 
som Simmons og Trout redegjør for i en artikkel om Hippies in College $\left.^{1}\right)$. Rekrutteringen til denne tilværelsen skjer i stor utstrekning via det mest politisk engasjerte lange hår blant studentene. Her kreves minst introduksjonsritualer, og studentpolitikerne har bruk for rekrutter. Politikken blir en koblingsmekanisme mellom nykommeren og det store skremmende og ukjente miljø. Men når koblingen er vel etablert, vil mange gå videre. Noen over i tradisjonelt studentliv, noen over i blomsterliv med st $\varnothing$ rre vekt på opplevelsesaspektet og estetikk. Men, og det er et viktig poeng, også fra blomstertilværelsen går det veier videre. Den blir ingen permanent tilværelse. Den langhårede fasen er i stor utstrekning en overgangsfase - helt $i$ analogi med mange andre slike faser $i$ menneskers liv - som russetid, pubertet eller studentaktivist. Bare få gror helt fast i overgangen. Én vei for blomsterstudentene går tilbake til de vanlige studier. Men en annen går fra Universitetet og over til det forfatterne kaller ,den avvikende hippie“", en med stor grad av promiskuitet og stor grad av stoff-bruk. Hvor mange som velger hvilke veier, vites ikke. Det mest relevante spørsmål blir jo dessuten: Hvor mange velger hvilke veier nå i forhold til hvor mange som gikk analoge veier tidligere?

Men kunnskapsmangelen må ikke helt paralysere oss. Det er vel ingen grunn til å betvile at en langhåret livsstil idag — sånn som vårt samfunn $\mathrm{i}$ hovedsak $\mathrm{er}$ organisert og med de verdier som i hovedsak er prioritert - representerer en belastning ut over det vanlige for majoriteten av deltakerne.

\section{Stoffbruk.}

Og så kommer endelig spørsmålet om de mulige avhengighetsskapende stoffene inn i bildet. Det er ingen tvil om at det finnes en åpenhet overfor bruk av marihuana og LSD blant representantene for den livsstil vi her omtaler. Det har sammenheng med mange ting, først og fremst interessen for indre liv, for opplevelser og for reiser i det ukjente. Men tilknytningen kan vel også i noen grad ses som et ledd i den generelle reaksjonsdannelsen mot den eldre generasjon, i dette tilfelle dennes bruk av andre stoffer — gammelmannsmidler som alkohol og barbiturater. Det er vel karakteristisk, vil mang en hippie si, at s $\varnothing \mathrm{vn}-$ skapende, sl $\varnothing$ vende midler dominerer våre foreldre, mens våkenhetsskapende, sinnsutvidende midler er våre valg.

Det kan de vel si, men får ikke derved noe betydelig overtak. De midler den gamle generasjon anvender bærer - ved siden av sine utvilsomme goder - også med seg omkostninger av en slik

1) Goeffrey Simmon og Grafton Trout. Hippies in College. From Teeny-Coppers to Drug Freaks. Transaction, 1967, 5, 27-32. 
art at hele vårt samfunn stadig får føle dem. Men noen visshet for at de nye midler vil bringe mindre skader, det er det så langt fra at vi har. Riktignok har omtalen av de nye midlene til dels vært så unyansert - med de omkostninger dette fører med seg — at det har provosert til debatt. Men denne debatt må ikke tolkes som en fullstendig uenighet om mulighetene for fare ved selve stoffene. Meget få har vel vært villige til å gå så langt som å antyde at disse midlene ikke kan romme, eller komme til å romme, ganske betydelige farer. Jeg vil i hvert fall ikke bli tatt til inntekt for et slikt standpunkt.

Alkohol og barbiturater er intimt sammenvevet med livsm $\phi$ nsteret til store kategorier i konsumentsamfunnet. Enda st $\varnothing$ rre er mulighetene for en sammenveving mellom de erkjennelsesutvidende stoffer og den langhårede livsstil blant antikonsumentene. Og selv om stoffene i begge tilfelle kan by på klare goder, så er det ved alkoholen klinkende klart, og ved marihuana høyst sannsynlig at stoffene for noen av brukerne og deres omgivelser kan bli til stor skade. Våre bestrebelser må vel derfor blant langhårede såvel som blant gråhårede, gå ut på å forsøke å dempe sammenvevingene mellom livsstil og stoffer, eller hvor dette ikke kan oppnås, søke å dempe skadevirkningene av selve stoffene.

Én teknikk i denne kamp må være å bruke erfaringene fra fors $\phi k$ ene på å bekjempe alkohol over til fors $\varnothing$ kene på å bekjempe de nye stoffer.

Situasjonen er ikke helt den samme. Alkoholen har vi, mens blomsterfolkets stoffer tross alt nesten ikke finnes i dette land. Det gjør disse stoffene farligere fordi det ikke er utviklet normer om hvorledes de skal hanskes, og det gjør også det totale forbud til en mer aktuell mulighet. Jeg har ingen store vanskeligheter med å akseptere den totale forbudslinje på det punkt i utviklingen som vi nå befinner oss. Men erfaringene fra alkoholforbudet tilsier at utviklingen må følges med vaktsomme $\varnothing y n e$, og forbudslinjen oppgis om omkostningene overstiger en viss margin. Forbud mot etterspurte varer trekker alltid til seg kriminelle elementer, og skaper nye.

En annen erfaring fra alkoholområdet, gjelder nytten av en differensiering mellom stoffene for å få ledet konsumet fra de farligste og over til de noe mindre farlige stoffer. Enda viktigere differensieringsmuligheter finnes blant de langhåredes stoffer. I omtalen av disse - og i den kriminalpolitikk vi f $\varnothing$ rer — må vi derfor fors $\phi$ ke å få til to ting på en gang. Vi må fors $\phi$ ke å hindre bruk av dem alle. Men vi må også — og det er her jeg mener vi gjør oss skyldige i farlige fors $\varnothing$ mmelser - vi må også fors $\phi k$ a å etablere skiller mellom stoffene. Disse skiller eller murer mellom dem b $\phi \mathbf{r}$ være dimensjonert etter et rimelig skjønn om faregrad. Det blir et viktig mål å få marihuanabrukere til 
ikke å gå over til noen i rekken av oppkvikkende stoffer, ikke til preludin, og for all del ikke til intraven $\varnothing$ s bruk av noe stoff.

En ytterligere erfaring fra alkoholområdet - og denne gangen om hvordan det ikke bør gjøres - finner man innen opplysningssektoren. Her må det - viktige unntak til tross - kunne sies at omtalen av alkohol i det norske samfunnet i stor utstrekning har vært preget av at korrelasjoner tolkes som årsaker, at ekstreme tilfelle av misbruk anvendes som eksplisitte eller implisitte illustrasjoner av hvorledes det går med alkoholbrukere i sin alminnelighet, og i det hele tatt at f $\varnothing$ lgetilstandene fremstilles karrikert og uten rimelig plass til de virkninger som får så mange til å benytte alkoholen. Alt sammen så ensidig at kontakten med brukergruppene alvorlig svekkes. Overfor en på forhånd opposisjonell og avvikende delkultur som de langhåredes, er alt dette spesielt uheldig. Ønsker man å minimalisere bruken av kjemiske stoffer blant disse - minimalisere sammenvevingen mellom livsstil og stoffbruk - må en vel først gjennom ekstrem grad av saklighet fors $\varnothing \mathrm{ke}$ å skape kontakt og fremfor alt tiltro, og deretter fors $\phi$ ke å få kulturbærerne, og særlig lederne, til selv å ta opp problemet. $\mathrm{Og}$ situasjonen er langt fra håpløs. Det finnes en affinitet mellom stoffbruk og livsstil. Men det er ingen absolutt sammenveving. Sammenkoblingen er svakere jo mer politisk orientert den langhårede er, og det finnes over hele spekteret klare oppfatninger om at „,reiser" også kan foretas på annet grunnlag enn det kjemiske. St $\varnothing$ rre adgang til — og respekt for - de mystiske og ekstatiske opplevelser vil formodentlig være til noen hjelp. Jeg sier formodentlig, fordi min usikkerhet er stor. Den viktigste forutsetning for å beskytte denne gruppen mot de farer som truer fra elementer i dens egen kultur, er presis kunnskap av en langt mer omfattende karakter enn jeg har kunnet formidle.

\section{Kampens farer.}

Den langhårede livsstil trues innenfra, ved muligheten for stoffbruk. Men den trues også utenfra, ved samfunnets massive kamp mot stoffene. Én hovedfare blir jo at man eliminerer en hel gruppe i bestrebelsene for å få bort ett trekk man engstes for ved denne gruppe. Og faren for at dette skal skje, blir så meget større fordi engstelsen - og kanskje også ergrelsen — overfor hele livsstilen kan gis legitimt utløp i kampen mot det ene uønskede trekk. Kampen mot stoffene blir lett en kamuflert kamp mot hele livsstilen, den blir i sine konsekvenser et maktmiddel mot det hele.

En annen fare er at man går enda lengere, og ikke bare kommer til å ramme langhårede, men også tiltak som yter service til en større gruppe langhårede enn i normalbefolkningen, eller som 
har et verdigrunnlag som på enkelte punkter står den livsstil nær som vi her diskuterer. ${ }^{1}$ ) De kjemiske midlene rommer farer. Noen av dem livsfarer. Men samtidtg er det jo klart at selve kampen mot stoffene har sine egne omkostninger, skaper nye problemer. Selv om midlene er farlige, så kan omkostningene ved enkelte kampformer bli enda farligere for summen av beskyttelsesverdige verdier og tiltak.

Men denne drøftelse av de farlige stoffene må ikke bringe oss ut av balanse. Hovedsaken er ikke stoffene. Hovedsaken er livsstilen. Og her er det vanskelig å forestille seg at noen bevisst styring skal kunne påvirke annet enn detaljer i den utvikling som er i gang. De største muligheter har kanskje nå som f $\varnothing \mathbf{r}$ innflytelser fra den sektor i samfunnet som har med фkonomi og handel å gjøre, samt den sektor som har med den ekstreme konflikt å gjøre. - Kommersialisering, krig — og muligens også sykdom og fysisk $n \varnothing d$ som f $\varnothing$ lge av stoffbruk og personlig vannr $\varnothing$ kt - kan utslette blomsterfolket og alt det står for - innenfra eller utenfra.

Men uansett fremtiden, så kan det vel allerede nå sies at blomsterfolket er i ferd med å tilføre både konsument-ideologien og dens grunnlag $\mathrm{i}$ utsatt behovstilfredsstillelse et langt hårdere knekk enn disse strømninger på meget, meget lenge er tilf $\varnothing$ rt fra noe annet hold. Bohemene var for få til å telle, og for rare til å bli h $\varnothing$ rt. De kristne troende for sterke i troen også på det jordiske gods. Blomsterfolket kunne fått all jordens herligheter, men har byttet bort sin f $\phi$ rstef $\phi$ dselsrett mot noen bjeller om halsen og en porsjon diffus innsikt. Ingen, hverken blomsterbarn eller vi andre, blir helt de samme etter dette.

Nils Christie.

1) I Norge synes saken om „Norsk Fors $\varnothing$ ksgymnas“ å være et typeeksempel. 